\title{
High School Mathematics Enrichment Book to Facilitate Students' Problem-Solving Ability
}

\author{
Rahayu Malini Pradyumnati ${ }^{1}$, Idris Harta ${ }^{2}$ \\ 1,2 Universitas Negeri Yogyakarta; Email: kagungan.aiu@gmail.com
}

\begin{abstract}
This study aims to produce a mathematics enrichment book to facilitate problem-solving ability based on the aspects of validity, practicality, and effectiveness. The research method used is research and development using the ADDIE model which includes the analysis, design, development, implementation, and evaluation stages. The research instruments used consisted of validation sheets, practicality assessment sheets, and test questions for mathematical problemsolving abilities. Validity and practicality data analysis was carried out by converting the total score of quantitative data obtained into five-scale qualitative data. Effectiveness of data analysis is done by determining the percentage of the number of accomplished students and the average test scores of mathematical problem-solving ability. The result of the research is a valid, practical, and effective mathematics enrichment book to facilitate problem-solving ability. The mathematics enrichment book developed has met validity criteria based on the validators' assessment with the average score in the high category, fulfills the practicality criteria based on the teachers' assessment with the excellent category, and meets the effective criteria based on the results of the mathematical problem-solving ability with the percentage of students accomplishment of $79.5 \%$ and the average score of the test results of 79 .
\end{abstract}

Keywords: Development; Enrichment Book; Problem-Solving Ability

\section{INTRODUCTION}

One indicator of success in mathematics learning is the achievement of mathematics learning objectives. One way to obtain information on the achievement of learning objectives is through students' learning outcomes. One ability that plays an important role in cognitive ability or learning outcomes is problem-solving ability. Problem-solving ability is when a person uses the knowledge acquired beforehand, the skills, as well as the understanding to meet the demands of a situation he rarely faced. The ability to solve problems is important to be developed and owned because through problem-solving activities, aspects of mathematical ability and other important things such as the application of rules to non-routine problems, the pattern of discovery, generalization, mathematical communication, and many others can be developed better (Suherman, 2001). In addition, Sriraman \& English (2010) say that problemsolving ability has a function to develop the mastery of concepts.

Based on the findings of several researchers, problems were found related to the mathematical problem-solving activities, namely the students' low problem-solving ability even when the problem to be solved does not present a high level of difficulty compared to their level. (Capriora, 2015; Ersoy \& Guner, 2015). The research conducted by Anggo (2012) concludes that students had difficulty in solving mathematical problems caused by their inability to translate contextual situations of the problems into formal mathematics.

Each learning process ends with an assessment. One of the benefits of doing an assessment is that the teacher can determine the follow-up to be given to the students. Enrichment acts as an experience that replaces, adds, or exceeds learning beyond what is 
usually given by the school. The important role of implementing enrichment is helping them to increase their appreciation of mathematics and to improve the profile of mathematics as a quite interesting subject to learn both inside and outside of school or for further learning (Jones \& Simons, 2000).

In the learning process, there are also several components that play a role in the success of achieving learning goals including teachers, students, teaching materials, and learning methods. A textbook is one of the printed materials most often used in the learning process. The use of textbook includes helping students to implement the curriculum because it is structured based on the applicable curriculum, becomes the teacher's source in determining teaching methods, gives students the opportunity to re-learn the lessons or to learn new lessons, and provides knowledge for teachers and students (Nasution, 1994). It is one of the ideal choices for certain situations because it fits the needs. Thus, the teacher is expected to be wiser in choosing books that are suitable for the learning situation and conditions. In addition, to select a textbook, the teacher can also develop books that will be used in the learning process according to the needs and characteristics of the students.

In previous studies, there have been many studies on the development of mathematics teaching materials carried out to facilitate the students in learning.(Andari \& Lusiana, 2014; Asmawati \& Wuryanto, 2014; Febriana, Sulur, \& Yudyanto, 2014; Fitri, 2011; Hartono \& Noto, 2017; Indraningtias, Diah, \& Ariyadi Wijaya, 2017; Melisa, 2016; Nisak, 2013; Rizkiah, Nasir, \& Komarudin, 2018; Rudiono, Dafik, \& Wahyuningrum, 2015; A. U. Sari, Farida, \& Putra, 2017; F. K. Sari, Farida, \& Syazali, 2016; Sulistyowati \& Sugiman, 2014; Supiyati \& Jailani, 2014; Supriadi, 2015; Susanti, Musdi, \& Syarifuddin, 2017; Wijayanti \& Sungkono, 2017; Yusnita \& Subanti, 2014)Serta penelitian yang membahas mengenai kemampuan pemecahan masalah siswa (Astriyani, 2016; Dewanti, 2018; E, S, \& Mashuri, 2015; Imamah \& Toheri, 2014; Komala, 2012; Pesona, 2018; Ramadhani, 2017; Susanti et al., 2017; Wulandari \& Supriyono, 2015) However, no previous research has been done in deve;oping a textbook to facilitate the students' problem-solving ability.

Based on the research that has been done before, the renewal in this study lies in the development of teaching materials in the form of a mathematics enrichment book. Given the limited research time in the development of teaching material, this research focuses on mathematics enrichment. The developed mathematics enrichment book is assisted by Geogebra to help the students to be easier to understand the material. The kinds of students' activities are presented to encourage students to learn mathematics/material in depth through independent discovery. Then, the purpose of this study is to produce a product in the form of a good mathematics enrichment book that can facilitate students' mathematical problem-solving ability.

\section{THE RESEARCH METHODS}

The type of this research is research and development. An enrichment book was developed using the ADDIE development model that composes of analysis, design, 
development, implementation, and evaluation stages. The procedure of the development is systematically shown in Figure 1.

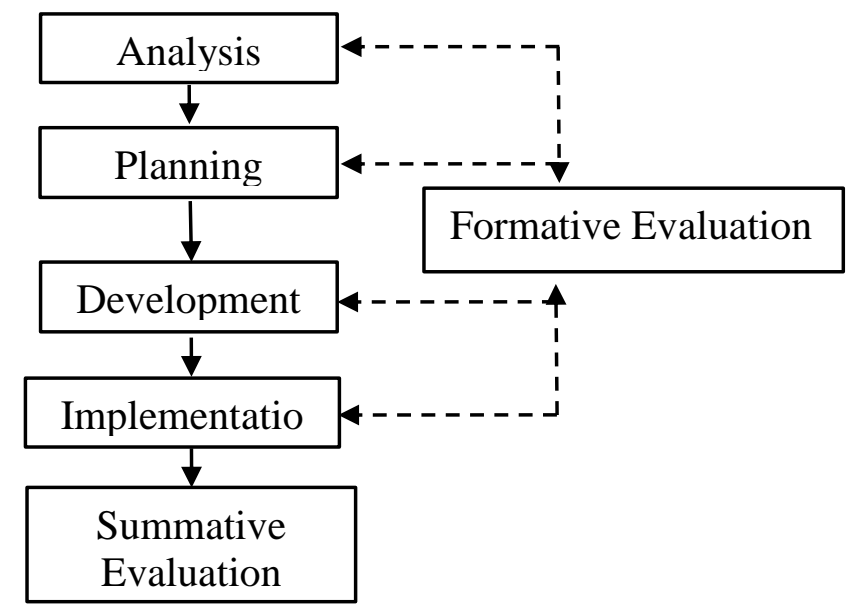

Figure 1. The Development Procedure Chart

The instruments used to collect the data were validation sheets, practicality assessment sheets, and test questions for mathematical problem-solving skills. Data obtained were in the form of quantitative and qualitative data. Data analysis was aimed at answering the research question that investigated whether the developed mathematics enrichment book met the valid, practical, and effective criteria. If these conditions are met, the developed enrichment book can be said to be a good product. The data analysis of validity and practicality of the enrichment book use was the conversion criteria. The data that was originally in the form of scores then changed into qualitative data using a scale of five. The following is a reference for the conversion of quantitative data into qualitative data.(Widoyoko, 2009)

Table 1. Data Conversion Criteria

\begin{tabular}{cc}
\hline Interval & Category \\
\hline$X>\underline{x}+1,8 S B_{i}$ & Excellent \\
$\underline{x}+0.6 S B_{i}<X \leq \underline{x}+1.8 S B_{i}$ & High \\
$\underline{x}-0.6 S B_{i}<X \leq \underline{x}+0.6 S B_{i}$ & Moderate \\
$\underline{x}-1.8 S B_{i}<X \leq \underline{x}-0.6 S B_{i}$ & Low \\
$X \leq \underline{x}-1.8 S B_{i}$ & Poor \\
\hline
\end{tabular}

Description:

$X=$ Respondent's score

$\underline{x}=$ Ideal average score $=\frac{1}{2}$ (ideal maximum score + ideal minimum score $)$

$S B_{i} \quad=$ Ideal standard deviation $=\frac{1}{6}$ (ideal maximum score - ideal minimum score $)$

Ideal maximum score: The highest theoretical score

Ideal minimum score: The lowest theoretical score

The validation scores were obtained using validation sheets. The validation was carried out by three mathematics lecturers. the validation sheet contained 45 statements consisted of 
evaluating aspects of content eligibility, presentation, language, and graphics. The minimum score that can be obtained is 45 and the maximum score is 225 . The following is a table of 2 validity categories of enrichment book based on the data conversion references.

Table 2. Validity Categories of the Enrichment Book

\begin{tabular}{cc}
\hline Interval Score & Category \\
\hline$X>189$ & Excellent \\
$153<X \leq 189$ & High \\
$117<X \leq 153$ & Moderate \\
$81<X \leq 117$ & Low \\
$X \leq 81$ & Poor \\
\hline
\end{tabular}

The developed mathematics enrichment book is said to be valid if the average validation score is in the high category.

The practicality score was obtained through practicality assessment sheet. The practicality assessment sheet was filled out by the teacher after carrying out the learning process using the developed enrichment book. The practicality assessment sheet contained 25 statements consisted of matter/content, presentation, language, and graphics aspects. The minimum score that can be obtained is 25 and the maximum score is 125 . The practicality assessment in each aspect is summed then converted into five-scale qualitative data as shown in the following table.

Table 3. The Practicality of the Enrichment Book

\begin{tabular}{cc}
\hline IntervalScore & Category \\
\hline$X>105$ & Excellent \\
$85<X \leq 105$ & High \\
$65<X \leq 85$ & Moderate \\
$45<X \leq 65$ & Low \\
$X \leq 45$ & Poor \\
\hline
\end{tabular}

The developed mathematics enrichment book is said to be practical if the result of the teacher's assessment is in the high category.

The effectiveness score of the mathematics enrichment book was obtained by looking at the degree of students' accomplishment of the learning objectives. It is intended for the developed textbook to facilitate students' problem-solving ability. Based on a review of several experts' opinions, the problem-solving ability indicators used in this study are presented in Table 4.

Table 4. The Synthesis of Problem -Solving Ability Indicator

\begin{tabular}{|c|c|}
\hline Measured Aspects & Indicators \\
\hline Identifying problems & $\begin{array}{l}\text { Writing what is known } \\
\text { Writing what is asked }\end{array}$ \\
\hline Making a plan for problem-solving & $\begin{array}{l}\text { Writing a formula/method what is possible to } \\
\text { solve the problem }\end{array}$ \\
\hline $\begin{array}{l}\text { Resolving the problem according to the plan } \\
\text { Explaining and interpreting the results }\end{array}$ & $\begin{array}{l}\text { Determining the problem-solving solution } \\
\text { Providing conclusions }\end{array}$ \\
\hline
\end{tabular}


The problem-solving test items consisted of 4 essay questions. The developed mathematics enrichment book is said to be effective if 1) the percentage of the students' achievement reaches or more than $75 \%$ and 2) the average score of problem-solving ability reaches and/or exceeds the school's standard of minimum competency which is 75 .

\section{THE RESULTS OF THE RESEARCH AND THE DISCUSSION}

This research was conducted within several stages based on the ADDIE development model. The analysis stage was carried out to analyze several things related to the research, the design stage was carried out to prepare the design of the mathematics enrichment book and the research instruments, the development stage was carried out to develop and improve the design of the mathematics enrichment book based on experts' suggestions. Furthermore, the implementation stage was carried out as an effort to test the mathematics enrichment book, and finally, the evaluation stage was carried out to determine the effectiveness of the mathematics enrichment book.

The first stage was the analysis stage. Based on the results of the needs analysis, it was known that the results of the international competencies in mathematics, final examination scores, and some previous studies show that mathematics learning outcomes, especially students' mathematical problem-solving ability were still low. Furthermore, based on the interview with the teachers, the enrichment learning was not carried out optimally and the books that support the implementation of enrichment programs were lacking. Based on the characteristic analysis, it was known that cognitive development in high school students should have entered the formal operational stage. At this stage, the students should possess the ability to think abstractly, reason logically, and draw conclusions from the information available. In addition, students should have been able to interpret what is learned and can plan for the next activity and think about every possibility to solve the problem. These characteristics students were taken into consideration in compiling the layout of mathematics enrichment book so that it can be used to the fullest. At the analysis stage, the material used was the conic section. The conic section was used as enrichment material for students whose test scores reached and/or exceeded the criteria of minimum mastery in circle material.

The second stage of the research was the design stage. The layout of mathematics enrichment books was designed by considering the characteristics of students at the high school level. In addition, several reference books were collected to enrich the material to be presented. The mathematics enrichment book presents various activities that can be carried out by students independently.

The third stage was the development stage. The results of the design stage were then validated. The validation was carried out by three validators by giving an assessment in the form of validation sheets. The results of the evaluation of the mathematics enrichment book can be seen in table 5 . 
Table 5. The Results of Validation Analysis

\begin{tabular}{lcccc}
\hline \multirow{2}{*}{ Components of Assessment } & \multicolumn{3}{c}{ Validator } & \multirow{2}{*}{ Average } \\
\cline { 2 - 4 } & I & II & III & \\
\hline Feasibility of Content & 59 & 61 & 63 & 61 \\
Presentation & 71 & 64 & 74 & 69.7 \\
Language & 32 & 32 & 31 & 31.7 \\
Layout & 26 & 24 & 29 & 26.3 \\
\hline Score & 188 & 181 & 197 & 188.7 \\
\hline Category & High & High & Excellent & High \\
\hline
\end{tabular}

The validation scores by the first and second validators were in the high categories while the validation score by the third validator was is in the excellent category. In general, the results of the evaluations from the three validators state that the developed mathematics enrichment book was valid and belonged to the high category so that it was feasible to be tested in the field.

The fourth stage was the implementation stage by testing the mathematics enrichment book developed in the learning process. The result of the implementation stage was in the form of data on the assessment of practicality and mathematical problem-solving ability. The practicality data were obtained based on the score of the assessment carried out by the teacher. The analysis results in the practicality aspect are presented in Table 6 .

Table 6. The Results of Practicality Analysis

\begin{tabular}{lccc}
\hline \multirow{2}{*}{ Component Assessment } & \multirow{2}{*}{ Maximum Score } & \multicolumn{2}{c}{ Assessment Result } \\
\cline { 3 - 4 } & & Score & Category \\
\hline Material / Content & 45 & 36 & High \\
Presentation & 35 & 32 & Excellent \\
Language & 25 & 22 & Excellent \\
Layout & 20 & 16 & High \\
\hline Score & 125 & 106 & Excellent \\
\hline
\end{tabular}

The score on practicality assessment sheet shows that the material/contents and layout components were in the high category. The scores for the presentation and language components were in the excellent category. In general, the developed mathematics enrichment book was in the excellent category so that it can be used practically in learning. The effectiveness of the mathematics enrichment book can be seen based on the results of tests of mathematical problem-solving ability. The results of the test are presented as follows.

Table 7. The Result of Problem-Solving Ability Test

\begin{tabular}{lcc}
\hline \multicolumn{1}{c}{ Description } & XI IPA 1 & XI IPA 2 \\
\hline Number of Students & 23 & 26 \\
Highest Score & 88 & 88 \\
Lowest Score & 65 & 52 \\
Average & 80 & 78 \\
Total Average & \multicolumn{2}{c}{79} \\
Accomplished & 18 students & 21 students \\
Unaccomplished & 5 students & 5 students \\
Percentage of Accomplished Students & $78.3 \%$ & $80.7 \%$ \\
\hline Percentage of Accomplished Students & \multicolumn{2}{c}{$79.5 \%$} \\
\hline
\end{tabular}


The mathematics enrichment book can be said as effective if 1) the percentage of the number of students who accomplish reaches/exceeds $75 \%$ and 2) the average score of problemsolving ability reaches/exceeds the criteria of minimum mastery determined by the school which is 75 . The results of the problem-solving ability test indicated that the overall percentage of students who accomplished was $79.5 \%$ (met the criteria) and the average score of students in both classes was 79 (met the criteria). Based on the two criteria in the category of effectiveness, it can be concluded that the developed mathematics enrichment book met the effective category and able to facilitate students' mathematical problem-solving ability.

In addition, the score of the test result in problem-solving ability can be reviewed based on each aspect in the problem-solving process. The percentage score of problem-solving ability based on each aspect of problem-solving can be seen in table 8 .

Table 8. The Percentage of Problem-Solving score for Each Aspect

\begin{tabular}{lccc}
\hline \multirow{2}{*}{ Aspects } & \multicolumn{2}{c}{ Class(\%) } & Average \\
\cline { 2 - 3 } & Science 1 & Science 2 & $(\%)$ \\
\hline Identifying problems & 94,6 & 96,2 & 95.4 \\
Making plans & 80,1 & 78,2 & 79,1 \\
Resolving problems & 72,8 & 70.8 & 71.8 \\
Interpreting the results & 70.7 & 68.6 & 69.6 \\
\hline
\end{tabular}

Based on Table 8 above, it was known that the aspect of the identifying problem got the highest percentage score or most students provided complete and correct answers to aspects while the aspects of interpreting the results obtained the lowest score percentage. In this aspect, the students were asked to provide conclusions based on the solved problems. The low percentage of interpreting the results aspect was caused by the students' difficulties in the previous stage, namely the problem-solving the stage. At the problem-solving stage, most students did not solve the problem completely in accordance with the plan previously made.

The final stage was the evaluation stage. The evaluation stage was conducted to assess the quality of the developed mathematics enrichment book. Based on validation data, it was known that the mathematics enrichment book met the validity criteria based on the validator's assessment (high category), fulfilled the practicality criteria based on the mathematics teacher's assessment (excellent category), and met the effective criteria based on the test data on mathematical problem-solving ability. The fulfillment of valid, practical, and effective criteria shows that the developed mathematics enrichment book has met the criteria of a good product and is able to facilitate students' mathematical problem-solving ability.

The results showed that the mathematics enrichment book developed was able to effectively facilitate the ability to solve mathematical problems. Based on the results of research and findings during the learning process, it is known that the developed product has been developed and arranged specifically in accordance with the goals and needs of students in which it will have a positive impact on learning outcomes. In addition, a book that presents various types of activities can encourage students to play a more active role during the learning process. This is in line with the results of research conducted by Nur Azlina and Mona that reveals that the students who learn using teaching materials that have been prepared and planned according 
to the needs and learning styles will show a significant increase (Mukmin \& Masood, 2015) There are several features in the developed mathematics enrichment book that are presented differently from other books, including:

1. Enrichment books present illustrations of the intersection of fields and conic section using the GeoGebra application to provide a clearer illustration of some curves, points, and lines.

2. The tutorial on making a conic section with the GeoGebra application is presented to help the users understand the steps for making the conic section.

3. The mathematics enrichment book presents various kinds of activities that can be carried out by students to strengthen their understanding of the materials.

4. The students are facilitated to do more discussion by presenting questions that must be answered.

5. The exercises are varied based on understanding, reasoning, and application.

6. Material applications in life are presented more diverse, including in the fields of health, architects, sports, and many others.

7. The end of each chapter provides learning journals as a means for students to measure their own ability and express difficulties in understanding the material presented.

8. The evaluation questions at the end of each discussion include a number of national examination questions, university enrollment tests, and national science Olympic.

\section{CONCLUSION AND SUGGESTION}

Based on the results of the research and discussion, it is concluded that the mathematics enrichment book has met validity criteria based on the validators' assessment with the average score in the high category, fulfills the practicality criteria based on the teachers' assessment with the excellent category, and meets the effective criteria based on the results of the mathematical problem-solving ability with the percentage of students accomplishment of $79.5 \%$ and the average score of the test results of 79.

Based on the conclusions, it is suggested for the future researchers to try to develop other learning tools such as student worksheets, computer applications, or books using various learning models in order to make the learning more interesting

\section{REFERENCES}

Andari, T., \& Lusiana, R. (2014). Pengembangan Perangkat Pembelajaran Dengan Menggunakan Pendekatan Quantum Learning Berbasis Needs Assesment Pada Materi Ruang-n Euclides. Jurnal Ilmiah Pendidikan Matematika, 3(1), 1-10.

Anggo, M. (2012). Metakognisi dan Usaha Mengatasi Kesulitan dalam Memecahkan Masalah Matematika. Aksioma, 1(1), 21-28.

Asmawati, R., \& Wuryanto. (2014). Keefektifan Model Pembelajaran LC 5E Dan TSTS Berbantuan LKPD Terhadap Hasil Belajar. Jurnal Kreano, 5(1), 26-32.

Astriyani, A. (2016). Peningkatan Kemampuan Pemecahan Masalah Peserta Didik Dengan Penerapan Model Pembelajaran Problem Posing. Fibonacci: Jurnal Pendidikan Matematika Dan Matematika, 2(1), 23-30. 
Capriora, D. (2015). Problem Solving-Purpose and Means of Learning Mathematics in School. Procedia-Social and Behavioral Sciences, 1(9), 1859-1864.

Dewanti, S. S. (2018). Profil Berpikir Kritis Mahasiswa PGMI dalam Memecahkan Masalah Matematika Dasar. Matematika Dan Pembelajaran, 6(1), 11-22.

E, S., S, M., \& Mashuri. (2015). Studi Perbedaan Keefektifan Pembelajaran LC-5E dan CIRC Terhadap Kemampuan Pemecahan Masalah Matematika. Jurnal Matematika Kreatif Inovatif, 6(1), 26-32.

Ersoy, P., \& Guner, P. (2015). The Place of Problem Solving and Mathematical Thinking in the Mathematical Teaching. The Online Journal of New Horizons in Education, 5(1), 120 130.

Febriana, L. C., Sulur, \& Yudyanto. (2014). Pengembangan Lembar Kerja Siswa (LKS) Fisika Materi Tekanan Mencakup Ranah Kognitif, Afektif dan Psikomotor Sesuai Kurikulum 2013 untuk Siswa SMP/MTs. Jurnal Universitas Negeri Malang, 2(1), 1-12.

Fitri, A. (2011). Pengembangan Perangkat Pembelajaran Statistika Dasar Bermuatan Pendidikan Karakter Dengan Metode Problem Based Learning. Jurnal PP, 1(2), 159-165.

Hartono, W., \& Noto, M. S. (2017). Pengembangan Modul Berbasis Penemuan Terbimbing untuk Meningkatkan Kemampuan Matematis pada Perkuliahan Kalkulus Integral. Jurnal JNPM ( Jurnal Nasional Pendidikan Matematika ), 1(2), 320-333.

Imamah, F. U., \& Toheri. (2014). Pengaruh Penggunaan Kombinasi Metode Pembelajaran Discovery Learning Dan Brain Storming Terhadap Kemampuan Pemecahan Masalah Pada Pokok Bahasan Himpunan. EduMa, 3(1), 120-137.

Indraningtias, A., Diah, \& Ariyadi Wijaya. (2017). Pengembangan Perangkat Pembelajaran Berbasis Pendekatan Matematika Realistik Materi Bangun Ruang Sisi DatarBerorientasi Pada Kemampuan Berpikir Kritis Siswa Kelas VIIISMP. Jurnal Pendidikan Matematika, 6(5), 1-10.

Jones, K. \& Simons, H. (2000). The Student Experience of Online Mathematics Enrichment. In: Nakahara T, Koyama M, editors. Proceedings of the 24th Conference of the International Group for the Psychology of Mathematics Education, (Japan), 3, 103-110.

Komala, E. (2012). Pembelajaran dengan Pendekatan Diskursif untuk Meningkatkan Kemampuan Pemecahan Masalah Matematis dan Self-Concept Siswa Sekolah Menengah Pertama. Tesis Pada SPS UPI. Tidak Dipublikasikan.

Melisa. (2016). Pengembangan Modul Berbasis Penemuan Terbimbing Yang Valid Pada Perkuliahan Kalkulus Peubah Banyak 1. LEMMA, 1(2), 21-27.

Mukmin, N. A. M., \& Masood, M. (2015). The Development of Self-Expressive Larning For Alebra Learning: An Inductive Learning Strategy. Procedia - Social and Behavioral Sciences, 197, 1847-1852.

Nasution. (1994). Teknologi Pendidikan. Jakarta: Bumi Aksara. 
Nisak, K. (2013). Pengembangan Perangkat Pembelajaran IPA Terpadu Tipe Connected pada Materi Pokok Sistem Ekskresi untuk kelas IX SMP. Jurnal Pendidikan Sains, 1(1), 8184.

Pesona, R. I. dan T. N. H. Y. (2018). Deskripsi Kemampuan Matematika Siswa Dalam Pemecahan Masalah Sistem Persamaan Linear Dua Variabel Berdasarkan Level. Jurnal Genta Mulia, 9(1), 99-109.

Ramadhani, R. (2017). Kemampuan Pemecahan Masalah Matematika Siswa SMA Melalui Guided Discovery Learning Berbantuan Autograph. JPPM, 10(2), 72-81.

Rizkiah, A. W., Nasir, \& Komarudin. (2018). LKPD Discussion Activity Terintegrasi Keislaman dengan Pendekatan Pictorial Riddle pada Materi Pecahan. Desimal : Jurnal Matematika, 1(1), 39-47.

Rudiono, T., Dafik, \& Wahyuningrum, E. (2015). Pengembangan Perangkat Pembelajaran Berbasis Rme Berorientasi Terciptanya Berfikir Tingkat Tinggi Materi Perbandingan Kelas VII. Pancaran, 4(1), 45-54.

Sari, A. U., Farida, \& Putra, F. G. (2017). Pengembangan Media Pembelajaran Berbantuan Web Dengan Pendekatan Etnomatematika Pada Pokok Bahasan Bangun Ruang Sisi Datar. In Prosiding Seminar Nasional Matematika dan Pendidikan Matematika (pp. 209-214). Lampung.

Sari, F. K., Farida, \& Syazali, M. (2016). Pengembangan Media Pembelajaran (Modul) berbantuan Geogebra Pokok Bahasan Turunan. Al-Jabar: Jurnal Pendidikan Matematika, $7(2), 135-151$.

Sriraman, B. \& English, L. (2010). Theories of Mathematics Education. India:

Suherman, E. (2001). Strategi Pembelajaran Matematika Kontemporer. Bandung: UPI.

Sulistyowati, Y., \& Sugiman. (2014). Pengembangan Perangkat Pembelajaran Bangun Ruang di SMP dengan Pendekatan Creative Problem Solving. Phytagoras, 9(2), 219-232.

Supiyati, \& Jailani. (2014). Pengembangan Perangkat Pembelajaran Bangun Ruang SMP dengan Pendekatan SAVI ( Somatik, Auditori, Visual, Intelektual). Jurnal Pendidikan Matematika, 9(2), 175-185.

Supriadi, N. (2015). Mengembangkan Kemampuan Koneksi Matematis Melalui Buku Ajar Elektronik Interaktif (Baei) Yang Terintegrasi Nilai-Nilai Keislaman. Al-Jabar: Jurnal Pendidikan Matematika, 6(1), 63-74.

Susanti, Musdi, E., \& Syarifuddin, H. (2017). Pengembangan Perangkat Pembelajaran Matematika Materi Statistik Berbasis Penemuan Terbimbing Untuk Meningkatkan Kemampuan Pemecahan Masalah Matematis Materi Statistika. Jurnal JNPM ( Jurnal Nasional Pendidikan Matematika ), 1(2), 305-319.

Widoyoko, S. (2009). Evaluasi Program Pembelajaran: Panduan Praktis Bagi Pendidik dan Calon Pendidik. Yogyakarta: Pustaka Belajar. 
Wijayanti, S., \& Sungkono, J. (2017). Pengembangan Perangkat Pembelajaran mengacu Model Creative Problem Solving berbasis Somatic, Auditory, Visualization, Intellectually. AlJabar: Jurnal Pendidikan Matematika, 8(2), 101-110.

Wulandari, K., \& Supriyono. (2015). Komparasi Kemampuan Pemecahan Masalah Antara Pembelajaran ARIAS Dan NHT Pada Geometri SMP. Unnes Journal of Mathematics Education, 4(1), 41-49.

Yusnita, R., \& Subanti, S. (2014). Pengembangan Perangkat Pembelajaran Berbasis Penemuan Terbimbing (Guided Discovery) Dengan Pendekatan Somatic, Auditory, Visual, Intellectual (SAVI) Pada Materi Pokok Peluang Kelas IX SMP Tahun Pelajaran 2013/2014. Jurnal Elektronik Pembelajaran Matematika, 2(4), 379-388. 